\title{
Augmented growth response to IGF-1 via increased IRS-1 in Chinese hamster ovary cells expressing kinase-negative insulin receptors
}

\author{
S. Inoue, K. Fukuda, T. Kudara, T. Igura, Y. Inui, S. Tamura, T. Hanafusa, S. Kawata, Y. Matsuzawa \\ Second Department of Internal Medicine, Osaka University Medical School, Yamadaoka 2-2, Suita 565, Japan
}

\section{Abstract}

Aims/hypothesis. Although both increased cell growth and impaired insulin signalling have been associated with diabetes, this association has not been investigated. Insulin-like growth factor-1 (IGF-1), a structural and functional analog of insulin, may play a part in the aberrant insulin receptor-mediated signalling observed in diabetes.

Methods. To investigate the consequence of this impaired signalling on cell proliferation and transformation, we transfected Chinese hamster ovary cells with cDNA encoding a kinase-defective insulin receptor. Results. In these mutant cells, the mitogenic and metabolic effects of insulin were reduced compared with control cells $(p<0.05)$ and this was due to a dominant negative effect. In contrast, these mutant cells showed a higher mitogenic response to IGF-1 than control cells, although IGF-1 receptor expression was similar in both cell lines. There was no statistically significant difference in mitogenic response, however, to platelet-derived growth factor, basic fibro- blast growth factor and heparin-binding epidermal growth factor-like growth factor. Variables of the IGF-1 signalling pathway, including tyrosine phosphorylation of insulin receptor substrate- 1 and activation of mitogen-activated protein kinase and phosphatidyl inositol 3 kinase, were also augmented in mutant cells. Insulin receptor substrate-1 message and protein abundance were higher in mutant than in control cells. Moreover, mutant cells had a higher mitogenic potential in low-serum-containing medium, suggesting that these cells have a transformed phenotype.

Conclusion/interpretation. These findings suggest that an impaired insulin signalling may upregulate insulin receptor substrate- 1 and that this, in turn, leads to increased IGF-1 signalling, a phenomenon that is possibly associated with increased cell growth in diabetes. [Diabetologia (1999) 42: 763-772]

Keywords Diabetes mellitus, insulin resistance, IGF1, IRS-1, cell growth.
Received: 27 October 1998 and in final revised form: 30 December 1998

Corresponding author: S. Inoue, Second Department of Internal Medicine, Osaka University Medical School, Yamadaoka 2-2, Suita 565, Japan

Abbreviations: PKC, Protein kinase C; PDGF- $\beta$, platelet-derived growth factor- $\beta$; $\mathrm{CHO}$, Chinese hamster ovary; PI3K, phosphatidyl inositol 3-kinase; ERK2, extracellular signal-regulated kinase-2; 2DOG, 2-deoxy-D-[U- $\left.{ }^{14} \mathrm{C}\right]$ glucose; PMSF, phenylmethanesulphonyl fluoride; MAPK, mitogen-activated protein kinase; $\mathrm{SH} 2$, Src homology-2.
The insulin receptor is an integral membrane protein comprised of two extracellular $\alpha$-subunits that bind insulin and two transmembrane $\beta$-subunits. The metabolic and growth-promoting effects of insulin are initiated by its binding to the $\alpha$-subunit of the insulin receptor. Upon binding to insulin, the insulin receptor undergoes autophosphorylation on tyrosine residues, which activates the intracellular tyrosine kinase of the $\beta$-subunit. This, in turn, stimulates the phosphorylation of cytoplasmic proteins, including insulin receptor substrate-1 (IRS-1) [1-5].

Diabetic complications, including diabetic nephropathy, retinopathy and atherosclerosis, are closely 
associated with increased cellular proliferation through the activation of growth factor mitogenic pathways. High glucose concentrations have been shown to enhance cellular proliferation through various mechanisms, including protein kinase $\mathrm{C}$ (PKC) activation, platelet-derived growth factor- $\beta$ (PDGF$\beta$ ) receptor upregulation and increased proteoglycan synthesis [6-9]. The correlation between impaired insulin signalling, another characteristic of diabetes, and increased growth factor pathways or cellular proliferation is not yet known.

Insulin-like growth factor-1, which has many of the structural and functional properties of insulin, is a mediator of cell growth and differentiation. This growth factor and insulin have been shown to possess structurally similar tyrosine kinase receptors and qualitatively similar metabolic and anabolic effects in vivo. Since the effects of both are mediated through phosphorylation of IRS-1 [10], IGF-1 may also contribute to diabetic complications. For example, in experimental diabetes, increases in renal IGF1 and IGF-1 receptor mRNA, and enhanced concentrations of IGF-1 receptor protein have been observed [11]. In addition, glomerular mesangial cells from diabetic mice have been found to express higher numbers of IGF-1 and IGF-1 receptors than cells from control mice $[12,13]$. In patients with proliferative diabetic retinopathy, enhanced concentrations of IGF-1 have been observed, suggesting that IGF-1 signalling may play a part in the pathogenesis of proliferative diabetic retinopathy [14-16]. There is also ample evidence that IGF-1 stimulates smooth muscle cell growth $[17,18]$. Insulin resistance and the aberrant effects of insulin and IGF-1 in vascular tissues are important risk factors for atherosclerosis and are thought to contribute to its development and the development of cardiovascular disease associated with Type II (non-insulin-dependent) diabetes mellitus [19-21].

To investigate the consequences of impaired insulin signalling on cell growth and transformation, we have established a Chinese hamster ovary $(\mathrm{CHO})$ cell line that stably expresses kinase-negative $\mathrm{Thr}^{1134}$ mutant insulin receptors, and we have examined the growth and response to growth factors, especially IGF-1, in these insulin-resistant cells.

\section{Materials and methods}

Materials. Recombinant human insulin and IGF-1 were obtained from Gibco BRL (Rockville, Md., USA). We obtained [ $\left.{ }^{125} \mathrm{I}\right]$ Insulin (74 TBq/mmol), [ $\left.{ }^{125} \mathrm{I}\right] \mathrm{IGF}-1 \quad(37 \mathrm{TBq} / \mathrm{mmol})$, $\left[{ }^{3} \mathrm{H}\right]$ thymidine $(37 \mathrm{MBq} / \mathrm{ml}), 2$-deoxy-D-[U- $\left.{ }^{14} \mathrm{C}\right]$ glucose $(7.4$ $\mathrm{MBq} / \mathrm{ml}), \mathrm{D}-\left[\mathrm{U}-{ }^{14} \mathrm{C}\right]$ glucose $(7.4 \mathrm{MBq} / \mathrm{ml}),\left[\gamma_{-}{ }^{32} \mathrm{P}\right] \mathrm{ATP}(9.25$ $\mathrm{MBq} / \mathrm{mmol})$, and $\left[\alpha^{-32} \mathrm{P}\right] \mathrm{dCTP}(37 \mathrm{MBq} / \mathrm{mmol})$ from Amersham Life Science (Tokyo, Japan). Rabbit polyclonal antibodies to insulin receptor $\beta$-subunit and carboxy-terminal IRS-1 and mouse monoclonal antibody to phosphotyrosine
(4G10) were purchased from Upstate Biotechnology Incorporated (Lake Placid, N.Y., USA). Rabbit polyclonal antibodies to IGF-1 receptor $\alpha$-subunit, IGF-1 receptor $\beta$-subunit, phosphatidyl inositol 3-kinase (PI3K) p85- $\alpha$ (Z-8) and extracellular signal-regulated kinase 2 (ERK2) (C-14), goat polyclonal antibodies to IRS-2, mouse nomoclonal antibody to Shc were purchased from Santa Cruz Biotechnology (Santa Cruz, Calif., USA). Peroxidase-conjugated rabbit antimouse and swine anti-rabbit immunoglobulin were purchased from Dako Japan (Tokyo, Japan). Protein A-agarose, protease inhibitors and phosphatase inhibitors were purchased from Sigma (St. Louis, Mo., USA) and fetal calf serum (FCS) was purchased from Irvine Scientific (Santa Ana, Calif., USA).

Expression plasmids. A cDNA fragment constituting the entire open reading frame of the human insulin receptor was subcloned in the sense orientation into the $\mathrm{XbaI}$ site of the mammalian expression vector, pEF Bos (Osaka Bioscience Institute, Osaka, Japan) (pEF Bos HIRC). Site directed mutants of insulin receptor cDNA were constructed from $\mathrm{pEF}$ Bos HIRC by the polymerase chain reaction (PCR), using the primers, 5'-ATCGGGACCTGACAGCGAGAAAC-3', 5'CTGTGGAAGAACGACACCTCTG-3', and 5'-GAGGGCAATGCCAGGGACATCA-3', to amplify an 803-bp cDNA fragment containing the mutation. This fragment was digested with HincII, and the resulting 684-bp fragment was substituted for the corresponding region of pEF Bos HIRC. The PCR-derived region of the mutant plasmid was sequenced to confirm that only the desired mutation was present ( $\mathrm{pEF}$ Bos HIR/Thr ${ }^{1134}$ ).

Transfection of $\mathrm{CHO}$ cells. Subconfluent $\mathrm{CHO}$ cells, grown in $6 \mathrm{~cm}$ dishes in Ham's F-12 medium containing FCS, were transfected with lipofectoamine (Gibco BRL) containing $1 \mu \mathrm{g}$ pSVE-neo, alone or together with pEF Bos HIR/Thr ${ }^{1134}$, at a molar ratio of 1:10. After 48-h exposure to DNA, the cells were trypsinized and replated at a 1:10 dilution. After $72 \mathrm{~h}$, $800 \mu \mathrm{g} / \mathrm{ml}$ geneticin (Gibco BRL) was added to the medium to select for neomycin-resistant cells, and this medium was changed every 4 to 5 days. Independent colonies were picked and maintained in Ham's F-12 medium, supplemented with $10 \%$ FCS, 100 units $/ \mathrm{ml}$ penicillin, $100 \mu \mathrm{g} / \mathrm{ml}$ streptomycin and $800 \mu \mathrm{g} / \mathrm{ml}$ geneticin at $37^{\circ} \mathrm{C}$ in $5 \% \mathrm{CO}_{2}$. Two independent clonal cell lines expressing a large number of $\mathrm{Thr}^{1134}$ insulin receptors were chosen for further studies $(\mathrm{CHO}-m u t 1$ and $\mathrm{CHO}-$ mut2).

Binding studies. Chinese hamster ovary cells were washed twice with binding buffer [Ham's F-12 supplemented with $25 \mathrm{mmol} / 1 \mathrm{HEPES}$ and $0.1 \%$ bovine serum albumin (BSA)] and incubated for $4 \mathrm{~h}$ at $4{ }^{\circ} \mathrm{C}$ in 24 -well plates containing the same buffer with various amounts of $\left[{ }^{125} \mathrm{I}\right]$ insulin or $\left[{ }^{125} \mathrm{I}\right] \mathrm{IGF}$ 1 in the absence or presence of a 100-fold excess of unlabelled insulin or IGF-1 [22]. The cells were washed with binding buffer and solubilized in $0.5 \mathrm{ml}$ lysing buffer $(0.1 \%$ SDS, $100 \mathrm{mmol} / \mathrm{l} \mathrm{NaOH})$. Cell bound and free radioactivity were measured with a gamma counter. Nonspecific binding to cells was usually less than $10 \%$ of total binding. Least-squares analysis was used to assess Scatchard plots.

Effects of growth factors on DNA synthesis. We assayed DNA synthesis by $\left[{ }^{3} \mathrm{H}\right]$ thymidine incorporation [23]. Subconfluent CHO cells seeded in 96-well plates were incubated for $24 \mathrm{~h}$ in Ham's F-12 medium supplemented with $0.1 \%$ BSA to induce quiescence. The medium was replaced with various concentrations of growth factors and, after $20 \mathrm{~h}$, cells were pulse-labelled 

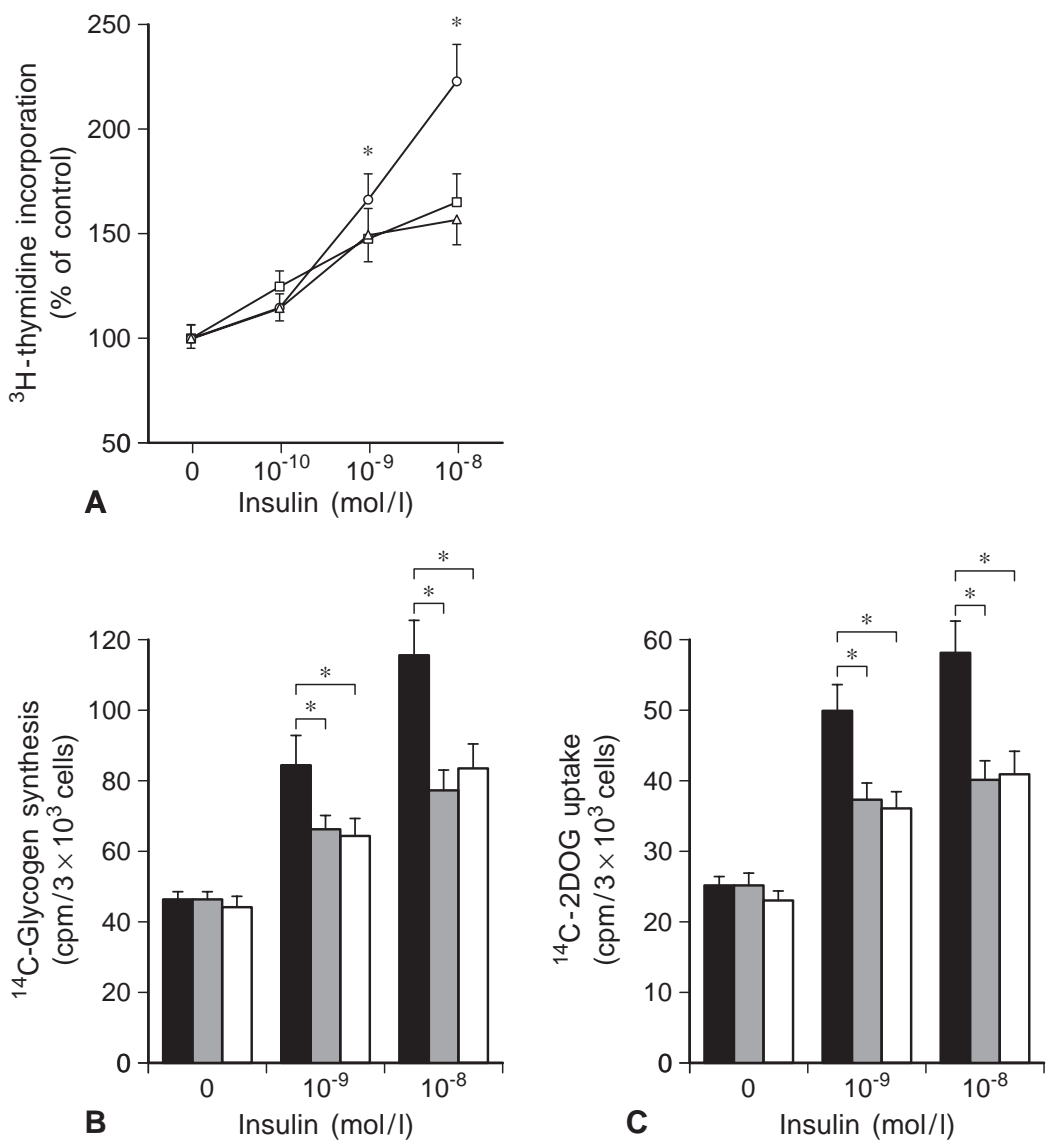

Fig.1A-C. Biological effect of insulin on $\mathrm{CHO}-$ neo and $\mathrm{CHO}-$ mut cells. Cells were treated with insulin, as described and $\left[{ }^{3} \mathrm{H}\right]$ thymidine uptake/incorporation into DNA (A, CHO-neo, $\square$ CHU-mut 1, $\triangle$ CHO-mut 2), 2-[ $\left.{ }^{14} \mathrm{C}\right]$ deoxyglucose uptake (B) and $\left[{ }^{14} \mathrm{C}\right]$ glucose incorporation into glycogen (C) were measured. Results are expressed as a percentage of the value in the absence of insulin ( $\mathrm{CHO}$-neo, $\mathrm{CHO}$-mut 1, $\square$ CHO-mut 2). Each value is the means \pm SD of triplicate determinations. $* p<0.05$

with $\left[{ }^{3} \mathrm{H}\right]$ thymidine $(37 \mathrm{KBq} /$ well) for $4 \mathrm{~h}$. Incorporated radioactivity was quantified with a $\beta$-plate system (Pharmasia LKB, Turku, Finland).

2-Deoxyglucose uptake. Chinese hamster ovary cells that were plated in six-well plates, were incubated with insulin at various concentrations for $1 \mathrm{~h}$ at $37^{\circ} \mathrm{C}$. Then 2-deoxy-D-[U_- $\left.{ }^{14} \mathrm{C}\right]$ glucose $(2 \mathrm{DOG})(14.8 \mathrm{KBq})$ and $0.1 \mathrm{mmol} / \mathrm{l}$ unlabelled $2 \mathrm{DOG}$ were added to each well and incubation was continued for a further $20 \mathrm{~min}$.

The cells were solubilized in $0.5 \%$ SDS and aliquots were assessed for protein content and radioactivity [24].

Glucose incorporation into glycogen. Chinese hamster ovary cells, plated in six-well plates, were incubated with insulin at various concentrations for $1 \mathrm{~h}$ at $37^{\circ} \mathrm{C}$. Then $74 \mathrm{KBq}$ of [U${ }^{14} \mathrm{C}$ ]glucose was added to each well and incubation was continued for $2 \mathrm{~h}$. The cells were solubilized in $0.5 \mathrm{ml} \mathrm{KOH}$ and boiled for $30 \mathrm{~min}$. To each sample $2 \mathrm{mg}$ glycogen and ethanol was added and the samples were incubated at $4{ }^{\circ} \mathrm{C}$. The precip-

itates were pelleted by centrifugation and solubilized in water, and radioactivity was determined by liquid scintillation counting [24].

Immunoprecipitation and western blotting. Subconfluent cells, treated with insulin or IGF-1, were washed twice with icecold phosphate-buffered saline (PBS) and lysed with TNE buffer containing $150 \mathrm{mmol} / \mathrm{l} \mathrm{NaCl}, 10 \mathrm{mmol} / \mathrm{l}$ TRIS-HCl $\mathrm{pH}$ 7.8, $1 \%$ NP-40, $1 \mathrm{mmol} / \mathrm{l}$ EDTA, $100 \mu \mathrm{mol} / 1 \quad \mathrm{Na}_{3} \mathrm{VO}_{4}$, $1 \mathrm{mmol} / \mathrm{l}$ phenylmethanesulphonyl fluoride (PMSF), 100 units $/ \mathrm{ml}$ aprotinine and $10 \mu \mathrm{g} / \mathrm{ml} \alpha_{2}$-macroglobulin. The samples were centrifuged, and the protein contents of the supernatants were measured with a Bio-Rad protein assay kit (Hercules, Calif., USA). The supernatants were incubated with the appropriate antibody and protein A-agarose for $2 \mathrm{~h}$ at $4{ }^{\circ} \mathrm{C}$ and the precipitates were washed four times with lysis buffer, resuspended in SDS sample buffer $(25 \mathrm{mmol} / \mathrm{l}$ TRIS-HCl $\mathrm{pH}$ $6.8,2 \%$ SDS, $10 \%$ glycerol, $0.05 \%$ bromophenolblue) and heated to $90{ }^{\circ} \mathrm{C}$ for $3 \mathrm{~min}$. Proteins were separated on an SDS-gel gradient and transferred to polyvinylidine difluoride membranes (Immovirone PVDF, Millipore, Bedford, Mass., USA) which were incubated with the appropriate primary antibody and then with the appropriate peroxidase-conjugated secondary antibody. Proteins were made visible by fluorography using an enhanced chemiluminescence system (Amersham).

Phosphatidyl inositol 3-kinase activity. Cell lysates (500 mg) were incubated with a polyclonal antibody against the p85 subunit of PI3K and protein A-agarose, and the precipitates were washed twice with $20 \mathrm{mmol} / \mathrm{l}$ TRIS-HCl (pH 7.8), $140 \mathrm{mmol} / \mathrm{l}$ $\mathrm{NaCl}, 1 \mathrm{mmol} / 1$ dithiothreitol, $1 \%$ NP-40, twice with $100 \mathrm{mmol} / \mathrm{l}$ TRIS-HCl (pH 7.4), $500 \mathrm{mmol} / \mathrm{l} \mathrm{LiCl}, 1 \mathrm{mmol} / \mathrm{l} \mathrm{di}-$ thiothreitol and twice with $10 \mathrm{mmol} / \mathrm{l}$ TRIS-HCl (pH 7.4), 

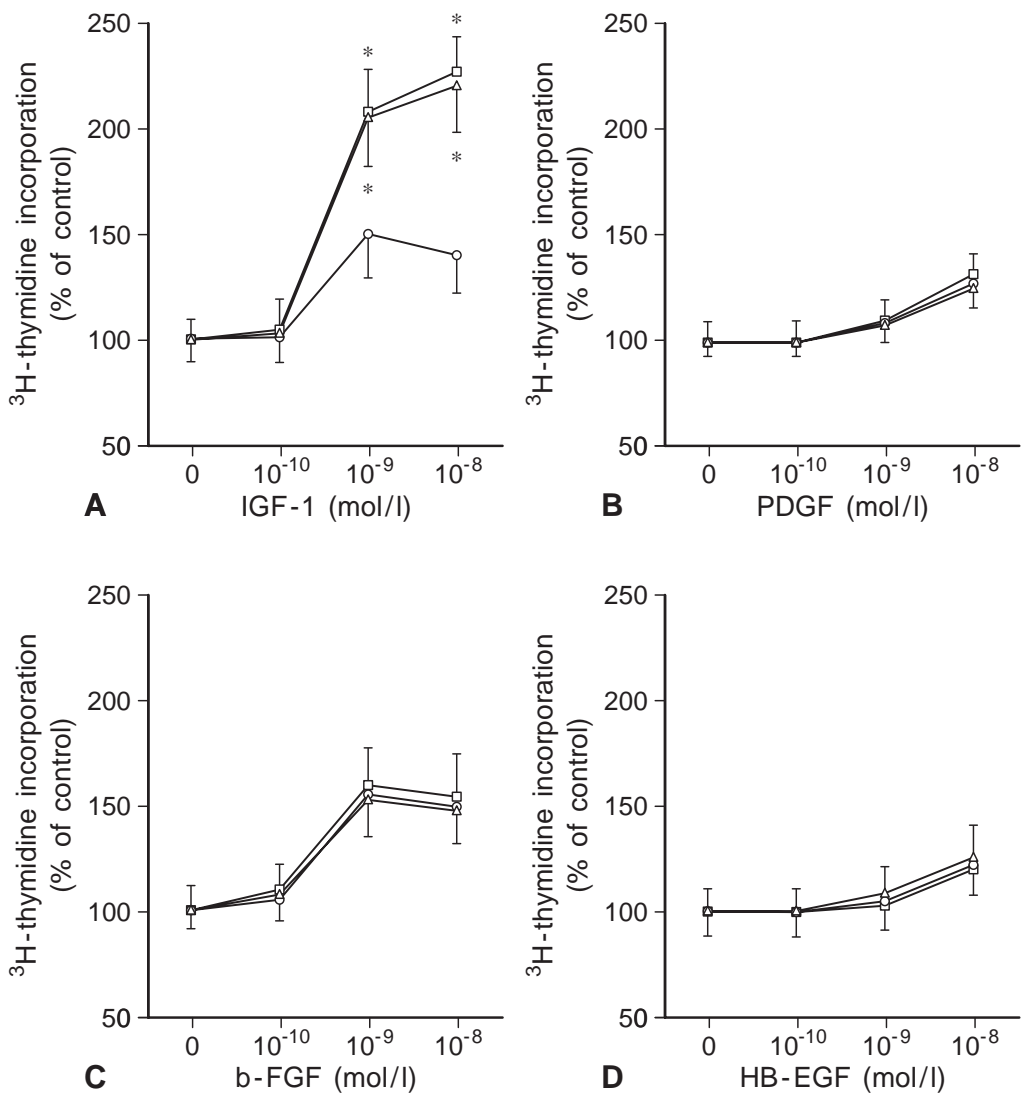

Fig. 2 A-D. Mitogenic effect of growth factors on CHO-neo and CHO-mut cells. Cells were stimulated with (A) IGF-1, (B) PDGF, (C) b-FGF or (D) HB-EGF and incorporation of $\left[{ }^{3} \mathrm{H}\right]$ thymidine was measured. Results are expressed as a percentage of the value in the absence of growth factor. Each value is the means $\pm \mathrm{SD}$ of triplicate determinations. ${ }^{*} p<0.05$. $\bigcirc \mathrm{CHO}$-neo, $\square \mathrm{CHO}$-mut1, $\triangle \mathrm{CHO}$-mut2

$100 \mathrm{mmol} / \mathrm{l} \mathrm{NaCl}, 1 \mathrm{mmol} / \mathrm{l}$ dithiothreitol. Each pellet was resuspended in $50 \mu \mathrm{l} 20 \mathrm{mmol} / \mathrm{l}$ TRIS-HCl (pH 7.5), $50 \mathrm{mmol} / \mathrm{l}$ $\mathrm{NaCl}, 10 \mathrm{mmol} / \mathrm{l} \mathrm{MgCl}_{2}, 0.5 \mathrm{mmol} / \mathrm{l}$ EGTA, $200 \mathrm{mg} / \mathrm{l}$ phosphatidyl-inositol, $200 \mathrm{mg} / \mathrm{l}$ phosphatidyl-serine, $120 \mu \mathrm{mol} / \mathrm{l}$ adenosine. The phosphorylation reaction was started by adding $10 \mu \mathrm{l}$ of a $40 \mu \mathrm{mol} / \mathrm{l}$ solution of ATP containing $148 \mathrm{KBq}$ $\left[\gamma-{ }^{32} \mathrm{P}\right]$ ATP. After $10 \mathrm{~min}$ at $30^{\circ} \mathrm{C}$, the reaction was stopped by adding $250 \mu \mathrm{l} 1 \mathrm{~N} \mathrm{HCl}$ and $80 \mu \mathrm{CHCl}_{3}$ :methanol (2:1). Lipid phosphorylation was analysed by thin-layer chromatography on silica gel plates coated with $1 \%$ potassium oxalate, followed by autoradiography.

Northern blot analysis of IRS-1 $m R N A$. Aliquots of total RNA $(20 \mu \mathrm{g})$, extracted from quiescent $\mathrm{CHO}$ cells [25], were electrophoresed through $1 \%$ agarose gels and transferred to nylon membranes (Hybond N; Amersham), which were incubated with a random primed $\left.{ }^{32} \mathrm{P}\right]$-labelled mouse IRS-1 gene. The membranes were washed and subjected to autoradiography, and mRNA abundance was measured by scanning laser densitometry and brought to normal against $18 \mathrm{~S}$ rRNA.

Measurement of cell growth in low serum concentration. Chinese hamster ovary cell proliferation in low serum concentration was assessed as described previously [26]. These cells

were seeded at a density of 10000 cells in six-well plates containing Ham's F-12 plus $0.1 \%$ FCS. Replicate plates were counted $24 \mathrm{~h}$ later (day 0 ) to confirm that all of the plates contained approximately the same initial cell number. The culture medium was changed every 2 days and cell counts were carried out each time. For each condition, experiments were carried out in triplicate.

Statistical analysis. All data is reported as means \pm SD and analysed by the non-paired Student's t-test. A $p$ value of less than 0.05 was considered statistically significant.

\section{Results}

Insulin receptor analysis. Binding experiments with $\left[{ }^{125} \mathrm{I}\right]$ insulin showed that the number of receptors on the surface of CHO-mut1 and CHO-mut2 cells was 84 and 97 times that on CHO-neo cells (58700/cell and 67200/cell vs 696/cell), whereas the affinity of insulin for its receptor was similar on both cell lines $\left(\mathrm{K}_{\mathrm{d}}: 0.89 \mathrm{nmol} / \mathrm{l}\right.$ and $\left.0.78 \mathrm{nmol} / \mathrm{l} \mathrm{vs} 0.72 \mathrm{nmol} / \mathrm{l}\right)$.

When we assayed cellular insulin receptor concentrations by immunoblotting, we found that the result was similar to that of the Scatchard analysis (data not shown).

Dominant negative effect of insulin receptor. To show that insulin-mediated signal transduction is reduced in CHO-mut cells and that this is due to a dominantnegative effect, we assayed insulin-induced $\left[{ }^{3} \mathrm{H}\right]$ thy- 
A

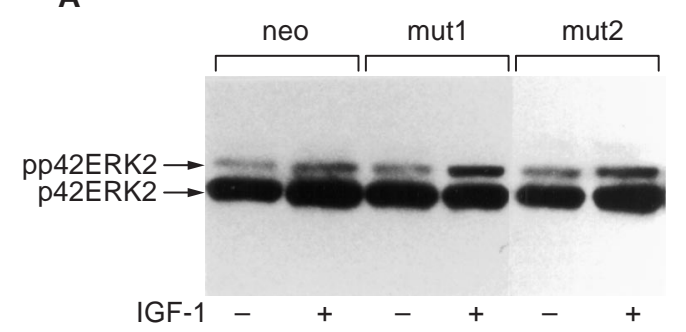

B

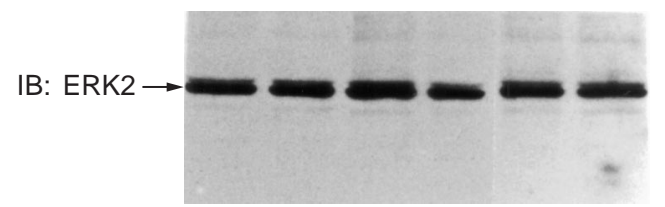

Fig.3. IGF-1-stimulated phosphorylation and total MAPK in CHO-neo and CHO-mut cells. (A) Cells were stimulated with $10^{-9} \mathrm{~mol} / \mathrm{l}$ IGF-1 and solubilized cell proteins were immunoblotted with anti-ERK2 antibody. The lower arrow indicates the band corresponding to dephosphorylated p42 MAPK and, the upper arrow indicates that corresponding to phosphorylated p42 MAPK. (B) Solubilized quiescent cell proteins were immunoblotted with anti-ERK2 antibody. The arrow indicates total levels of p42 MAPK

midine incorporation, glucose uptake and glycogen synthesis in these cells.

Basal levels of all three variables were similar in CHO-mut and CHO-neo cells (Fig. 1). Treatment of $\mathrm{CHO}-$ mut 1 and 2 cells with $10^{-9} \mathrm{~mol} / \mathrm{l}$ insulin reduced $\left[{ }^{3} \mathrm{H}\right]$ thymidine incorporation $10 \%$ and $11 \%$, and treatment with $10^{-8} \mathrm{~mol} / \mathrm{l}$ insulin reduced incorporation $30 \%$ and $26 \%$ compared with control cells (Fig. 1A). Similarly, in CHO-mut cells, 2DOG uptake was decreased $27 \%$ and $20 \%$ at $10^{-9} \mathrm{~mol} / \mathrm{l}$ insulin and $31 \%$ and $30 \%$ at $10^{-8} \mathrm{~mol} / \mathrm{l}$ insulin (Fig. $1 \mathrm{~B}$ ), and glucose incorporation into glycogen was decreased $21 \%$ and $23 \%$ at $10^{-9} \mathrm{~mol} / \mathrm{l}$ insulin and $33 \%$ and $28 \%$ at $10^{-8} \mathrm{~mol} / \mathrm{l}$ insulin compared with control cells (Fig. 1C).

These results suggest that the kinase-deficient receptor exerts a trans-dominant-negative effect by forming heterodimers with endogenous murine receptors $[1,27,28]$.

Mitogenic response to growth factors. Compared with $\mathrm{CHO}-$ neo cells, $\left[{ }^{3} \mathrm{H}\right]$ thymidine incorporation into CHO-mut 1 and 2 cells was increased $32 \%$ and $30 \%$ by stimulation with $10^{-9} \mathrm{~mol} / \mathrm{l}$ and $47 \%$ and $39 \%$ by stimulation with $10^{-8} \mathrm{~mol} / \mathrm{l} \mathrm{IGF-1}$ (Fig. 2A). We observed no differences between these cell lines, however, in response to PDGF (Fig.2B), b-FGF (Fig. 2C) or HB-EGF (Fig. 2D).

Insulin-like growth factor-1-stimulated MAPK phosphorylation. Mitogen-activated protein kinase (MAPK) is a serine/threonine kinase that is rapidly activated in response to insulin and IGF-1; it has been implicated in cellular proliferation. We assayed the phosphorylation state of p42 (ERK2) MAPK in CHO-mut and CHO-neo cells by an electrophoretic mobility shift assay where the activated, phosphorylated form of ERK2 displays a slower electrophoretic mobility. When stimulated with $10^{-9}$ mol/l IGF-1, the amount of phosphorylated p42 MAPK in CHO-mut cells was higher than that in CHO-neo cells (Fig. 3A). We also assayed total levels of MAPK in CHO-mut and $\mathrm{CHO}-$ neo cells by western blotting and found no difference between these cell lines (Fig. 3B). The enzymatic activity of MAPK, assessed by in-gel phosphorylation [29] was parallel to the results of the gel-shift assay (data not shown).

Insulin-like growth factor-1-stimulated PI3K activation. Phosphatidyl inositol 3-kinase is another major component of the IRS-1 mediated insulin and IGF-1 signalling pathways; it contains two Src homology-2 (SH2) domains in its $85-\mathrm{kDa}$ subunit that bind to tyrosine-phosphorylated IRS-1.

We assayed activated PI3K in CHO-mut and CHO-neo cells by immunoprecipitating solubilized cell proteins with anti-IRS-1 antibody and immunoblotting with anti-PI3K antibody. After stimulation with $10^{-9} \mathrm{~mol} / \mathrm{l} \mathrm{IGF}-1$, the amount of activated PI3K in $\mathrm{CHO}-m u t$ cells was higher than that in $\mathrm{CHO}-$ neo cells (Fig. 4A).

We also assayed PI3K activity in these cells by measuring $\left[\gamma-{ }^{32} \mathrm{P}\right]$ ATP incorporation into phosphatidyl inositol; PI3K enzyme activity was greater in stimulated CHO-mut cells than in CHO-neo cells (Fig. 4B).

IGF-1 receptor analysis. When we assayed IGF-1 receptors by binding studies with [ $\left.{ }^{125} \mathrm{I}\right] \mathrm{IGF}-1$, we found that both the affinity and the number of IGF-1 receptors on CHO-mut1 and 2 cells and $\mathrm{CHO}$-neo cells were similar, with a $\mathrm{K}_{\mathrm{d}} 1.52$ and $1.48 \mathrm{nmol} / \mathrm{l}$ compared with $1.51 \mathrm{nmol} / 1$, respectively, and a receptor number of 9018 and 9978/cell compared with 9752/cell, respectively.

Stimulation of IGF-1 receptor tyrosine phosphorylation by IGF-1. We assayed tyrosine phosphorylation of IGF-1 receptor in CHO-mut and CHO-neo cells by immunoprecipitation of solubilized cell proteins with anti-IGF-1 receptor $\beta$-subunit antibody and immunoblotting with anti-phosphotyrosine antibody. Insulin-like growth factor-1 receptor phosphorylation by IGF-1 was similar in both cell lines (Fig. 5). Western blotting with an anti-IGF-1 receptor $\alpha$-subunit antibody showed a similar concentration of IGF-1 receptor on CHO-mut and CHO-neo cells (Fig. 5), suggesting that augmented IGF-1 signalling in CHO-mut cells was not due to changed IGF-1 receptor expression or affinity. 
A

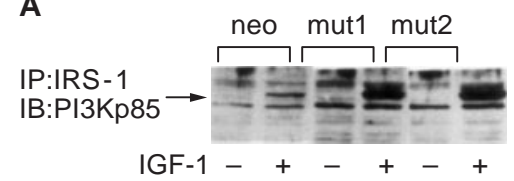

B

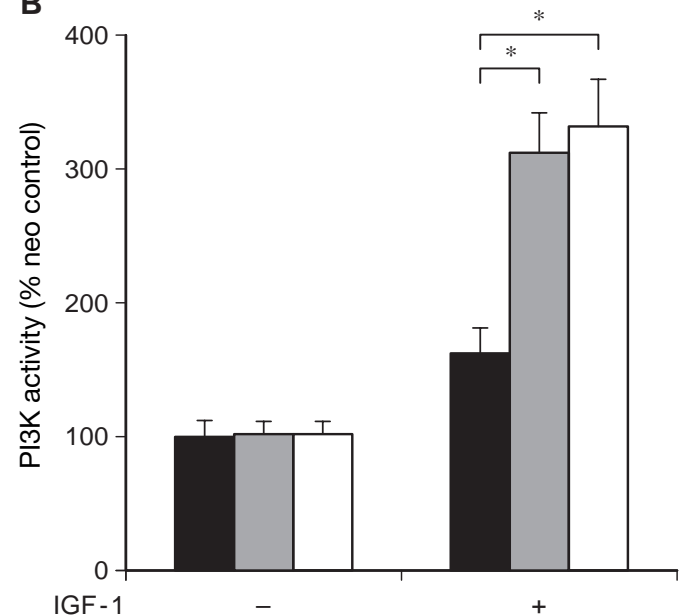

Fig. 4A, B. Insulin-like growth factor-1-stimulated activation of PI3K in CHO-neo and CHO-mut cells. (A) Cells were stimulated with $10^{-9} \mathrm{~mol} / \mathrm{l} \mathrm{IGF-1,} \mathrm{and} \mathrm{solubilized} \mathrm{cell} \mathrm{proteins} \mathrm{were}$ immunoprecipitated with anti-IRS-1 antibody followed by immunoblotting with anti-PI3K antibody. The arrow indicates the $35 \mathrm{kDa}$ band, corresponding to activated PI3K. (B) Representative result of the PI3K enzyme assay. Incorporation of label into phosphatidylinositol and phosphatidylserine was measured as described. Quantification of results, using a Bio Image Analyzer. Values are expressed as a percentage of the control. Each value is the means $\pm \mathrm{SD}$ of triplicate determinations. $* p<0.05$ CHO-neo, $\mathbb{Z}$ CHO-mut $1, \square$ CHO-mut 2

Stimulation of IRS-1 tyrosine phosphorylation by $I G F-1$. Insulin receptor substrate-1 is a major intracellular substrate for the tyrosine phosphorylases of insulin receptor and IGF-1 receptor; it is phosphorylated immediately following insulin or IGF-1 stimulation, and it has a key role in the intracellular signalling cascade that includes MAPK and PI3K [1-3, 30, 31].

We assayed tyrosine phosphorylation of IRS- 1 in CHO-mut and CHO-neo cells by immunoprecipitation of solubilized cell proteins with anti-IRS-1 antibody and immunoblotting with anti-phosphotyrosine antibody. Although IRS-1 phosphorylation was nearly undetectable in the absence of IGF-1, it was higher in CHO-mut cells than in CHO-neo cells after stimulation with $10^{-9} \mathrm{~mol} / 1$ and $10^{-7} \mathrm{~mol} / 1 \mathrm{IGF}-1$ (Fig. 6).

When we assayed IRS-1 expression by western blotting with anti-IRS-1 antibody, we found it was higher in CHO-mut cells than in $\mathrm{CHO}-$ neo cells (Fig.6).

Stimulation of IRS-2 and Shc tyrosine phosphorylation by IGF-1. Insulin receptor substrate- 2 and Shc are also important substrates of insulin and IGF-1 re-

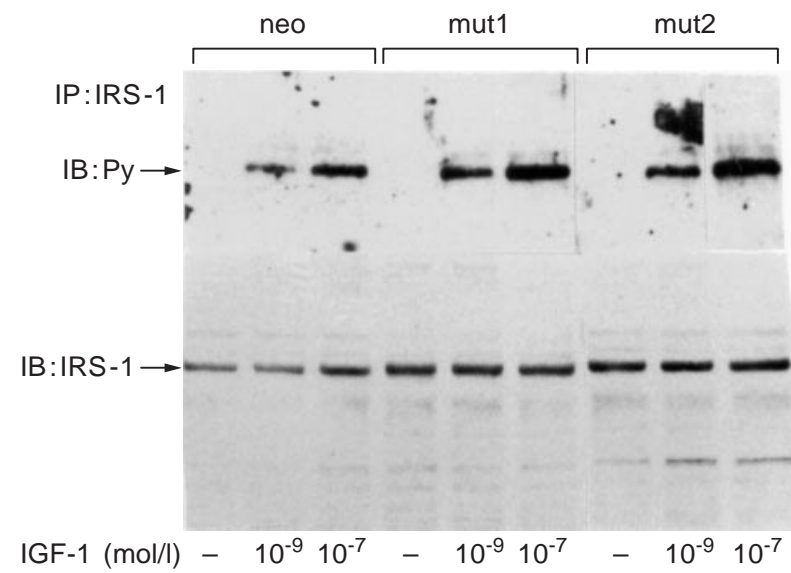

Fig. 5. Effect of IGF-1 on tyrosine phosphorylation and expression of IGF-1 receptor in $\mathrm{CHO}-$ neo and $\mathrm{CHO}-$ mut cells. Solubilized cell proteins from IGF-1-stimulated CHO-mut and $\mathrm{CHO}$-neo cells were immunoprecipitated with anti-IGF-1 receptor $\beta$-subunit antibodies followed by incubation with anti-phosphotyrosine antibody. The upper arrow indicates $95 \mathrm{kDa}$ band, corresponding to phosphorylated IGF-1 receptor $\beta$-subunit. Lysates were immunoblotted with anti-IGF-1 receptor $\alpha$-subunit antibodies. The lower arrow indicates a 135 KDa band, corresponding to the $\alpha$-subunit of the IGF-1 receptor

ceptors. So, we measured the tyrosine phosphorylation and protein of IRS-2 and Shc and found no statistically significant differences in the phosphorylation after stimulation with IGF-1 or in the expression of IRS-2 and Shc by western blotting (Fig. 7).

Insulin receptor substrate-1 $m R N A$ expression. To study whether the increased IRS-1 protein expression is due to an increase in gene transcription, we assayed IRS-1 mRNA expression by northern blotting. We observed a twofold increase in message abundance in CHO-mut cells compared with $\mathrm{CHO}$-neo cells (Fig. 8).

Cell growth in low serum concentration. Cells overexpressing IRS-1 have been reported to display transformed phenotypes [26, 32, 33].

To determine whether the increased IRS-1 expression observed in CHO-mut cells has any effect on cell growth, we investigated cell proliferation in medium containing $0.1 \%$ FCS. We observed increased growth of CHO-mut compared with $\mathrm{CHO}-$ neo cells, resulting in about double the cell number in 8 days (Fig.9).

\section{Discussion}

Although hyperglycaemia as well as diabetic complications, including retinopathy, nephropathy and atherosclerosis, have been shown to be closely associated with increased cellular proliferation, the effect of impaired insulin signalling, another characteristic of diabetes, on cell growth regulation had not been clar- 


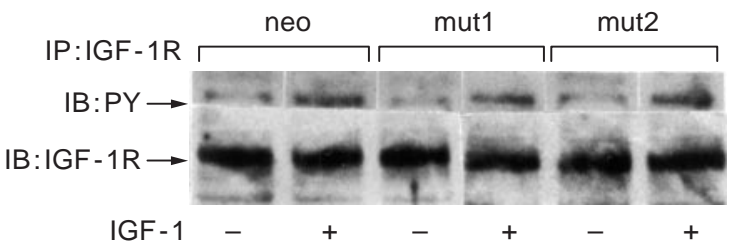

Fig. 6. Effect of IGF-1 on tyrosine phosphorylation and expression of IRS-1 in CHO-neo and CHO-mut cells. Solubilized cell proteins from IGF-1-stimulated $\mathrm{CHO}-m u t$ and $\mathrm{CHO}-$ neo cells were immunoprecipitated with anti-IRS-1 antibodies followed by incubation with anti-phosphotyrosine antibody or anti-IRS-1 antibodies. The upper arrow indicates a $185 \mathrm{kDa}$ band, corresponding to phosphorylated IRS-1. The lower arrow indicates that, corresponding to IRS-1

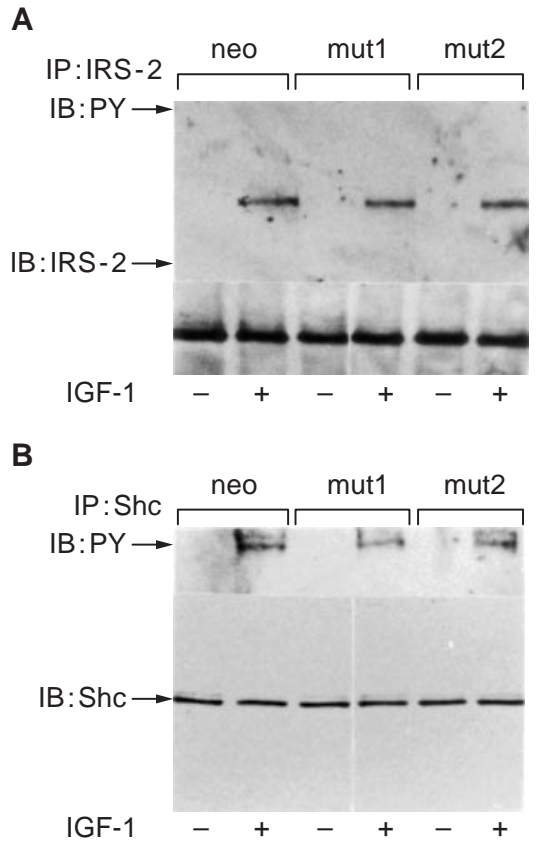

Fig. 7A, B. Effect of IGF-1 on tyrosine phosphorylation and expression of IRS-2 and Shc in CHO-neo and CHO-mut cells. Solubilized cell proteins from IGF-1-stimulated CHO-mut and CHO-neo cells were immunoprecipitated with anti-IRS-2 (A) or She (B) antibodies followed by incubation with antiphosphotyrosine antibody or anti-IRS-2 or Shc antibodies. (A) The upper arrow indicates a $195 \mathrm{kDa}$ band, corresponding to phosphorylated IRS-2. The lower arrow indicates that, corresponding to IRS-2. (B) The upper arrow indicates a $52 \mathrm{kDa}$ band, corresponding to phosphorylated Shc. The lower arrow indicates that, corresponding to Shc

ified. We therefore, investigated the mitogenic responsiveness to various growth factors in $\mathrm{CHO}$ cells expressing kinase-negative insulin receptors.

Although the effects of b-FGF, PDGF and HBEGF on $\left[{ }^{3} \mathrm{H}\right]$ thymidine incorporation were similar in $\mathrm{CHO}-m u t$ and control cells, the mitogenic response to insulin was reduced in CHO-mut cells. In contrast, the mitogenic effect of IGF-1, which shares part of the insulin-signalling pathways and activates MAPK and PI3K, was increased in CHO-mut cells. Since
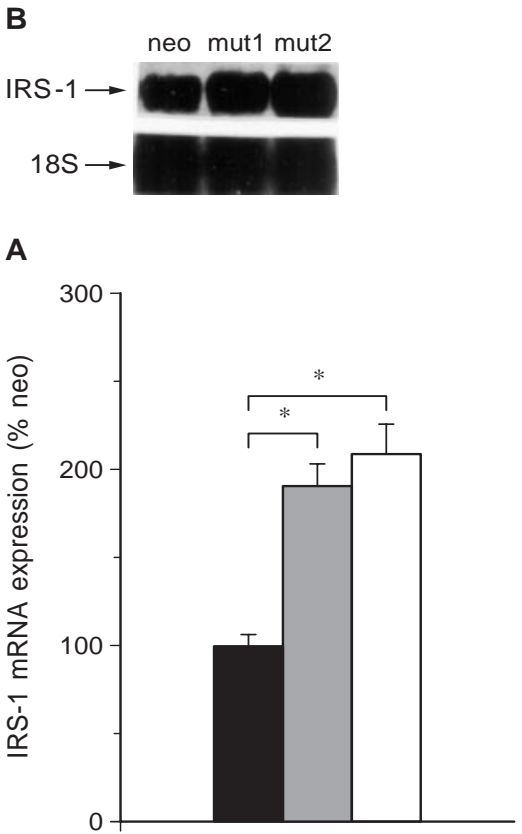

Fig. 8 A, B. Insulin receptor substrate- $1 \mathrm{mRNA}$ expression in CHO-neo and CHO-mut cells. Total RNA (20 $\mu \mathrm{g})$ isolated from quiescent $\mathrm{CHO}-$ neo and $\mathrm{CHO}$-mut cells was fractionated in a $1 \%$ agarose gel and hybridized with $\left[{ }^{32} \mathrm{P}\right]$-labelled IRS-1 cDNA. As an internal standard 18S rRNA was used. Representative result of the IRS-1 mRNA expression (A). Quantification of results, using a Bio Image Analyzer. Each value is the means $\pm \mathrm{SD}$ of triplicate determinations. $* p<0.05$ (B) - CHO-neo, שS CHO-mut1, $\square$ CHO-mut2

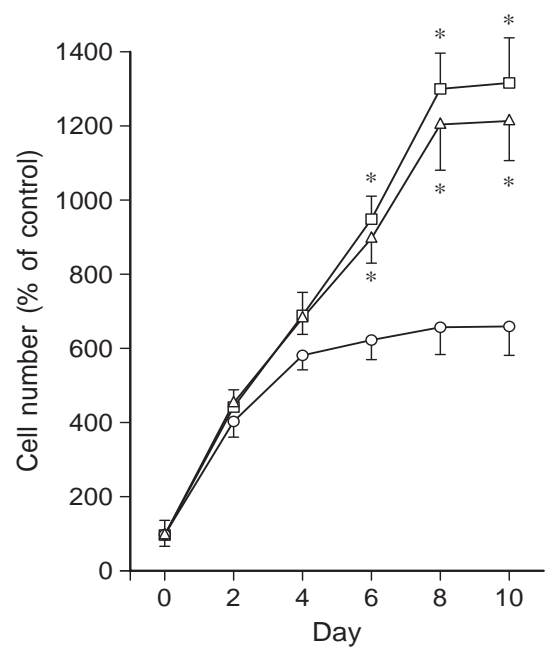

Fig. 9. Cell proliferation in medium containing low serum. Cells were cultured for 10 days in Ham's F-12 medium containing $0.1 \%$ FCS and in the absence of growth factors. Each value is the means $\pm \mathrm{SD}$ of triplicate determinations. $* p<0.05$. $\bigcirc \mathrm{CHO}$-neo, $\square \mathrm{CHO}$-mut $1, \triangle \mathrm{CHO}$-mut 2

IGF-1 receptor expression was not altered in CHOmut cells, our findings suggest that the IGF-1 signalling pathway is augmented in insulin-resistant CHOmut cells through a post-receptor mechanism. 
The authors who reported the A/T 1134 mutant investigated the insulin response in $\mathrm{CHO}$ cells overexpressing this mutant. They found an inhibition of glycogen synthesis in response to insulin in mutant cell lines, however, insulin-stimulated thymidine incorporation and glucose uptake in two mutant cell lines were not different from those in control cells [24]. This could have resulted from differences in insulin concentration and time of stimulation. In a similar study using another kinase-deficient mutant of the insulin receptor $(\mathrm{A} / \mathrm{K} 1018)$, it was reported that both insulin and IGF-1 responses were decreased in the mutant cell lines [34]. It has been proposed that mutant insulin receptors form hybrid oligomers with wild-type IGF-1 receptors and that such oligomers are defective in kinase activity. In this respect, the variability of the IGF-1 response could be attributed to the different phenotypic expression of heterozygous mutations in the insulin receptor kinase domain. Compared with the A/K1018 mutant insulin receptor, the A/T1134 mutant insulin receptor could have a different phosphorylation site for the receptor and IRS1 , a different binding site and affinity with IRS-1 and cause different IRS-1 metabolism, resulting in augumented IGF-1 signalling. It might be interesting to include both insulin receptor mutations for comparison to establish whether the enhanced IGF-1 signalling is a phenomenon linked to insulin resistance, or whether this is unique to the $\mathrm{Thr}^{1134}$ insulin receptor mutation. It is also reported that the $\mathrm{Ile}^{1153}$ mutant receptor retains the ability to bind IRS- 1 and that sequestration or serine/threonine phosphorylation of the substrate or both may provide an alternative molecular explanation for the dominant negative effect of the mutant receptor to inhibit phosphorylation of IRS-1 and inhibition of IRS-1 tyrosine phosphorylation by kinase competent IGF-1 receptors [35, 36]. Because this explanation is applicable in the presence of insulin stimulation, it can be speculated that in the quiescent condition, mutant insulin receptors have no effect on IRS-1 phosphorylation by the IGF-1 receptor and that sequestration and serine/threonine phosphorylation of IRS-1 by mutant insulin receptors influence IRS-1 metabolism, resulting in increased IRS-1 expression and augumented IRS-1 phosphorylation by IGF-1 stimulation.

In patients with naturally occuring insulin receptor mutations, IGF-1 signalling has been shown to be impaired in vivo but it was reported that this could be due to the impaired production of IGF-1 and accerelated excretion by impaired IGF binding protein-3 production [37]. Moreover, it has been reported that treatment with recombinant human IGF-1 improved glucose metabolism in patients with insulin receptor mutations and severe insulin resistance [38-40] therefore responsiveness to IGF-1 is possibly not so impaired and could even be increased in some conditions in vivo. Our observations of augumented IGF-
1 signalling suggest new therapeutic roles and potential for recombinant human IGF-1 in subjects with insulin receptor mutations. At the same time, however, IGF-1 treatment for a prolonged period may accerelate progression of diabetic complications by cell growth promotion.

Insulin receptor substrate- 1 acts as a multiple docking protein by binding to downstream signaltransduction molecules in response to activation by insulin or IGF-1. Phosphorylation of multiple tyrosine residues of IRS-1 by insulin or IGF-1 receptors has been shown to result in the association of IRS-1 with the $\mathrm{SH} 2$ domains of other cytoplasmic signalling proteins, including PI3K, Syp, GRB2 and Nyc [41]. Consequently, IRS-1 mediates the activation of PI3K, p70S6-kinase, p21Ras and MAPK, resulting in the promotion of glucose uptake, glycogen synthesis, mitogenesis and gene expression, thus serving as an important point in the insulin or IGF-1 action pathway at which the signal diverges to produce the multiple biological effects of the hormone. When we assayed the effects of IGF-1 on IRS-1 in CHO-mut cells, we found that tyrosine phosphorylation of this protein, as well as the protein expression, were higher in CHO-mut than in CHO-neo cells. This indicates that the increased IRS-1 phosphorylation, MAPK activity and PI3K activity observed in the former could be due to, and parallel, increased IRS-1 protein expression.

Insulin receptor substrate- 1 has been found to be overexpressed in human hepatocellular carcinomas, suggesting that this protein may be important in hepatocyte transformation, as well as in the physiological proliferation of these cells [26, 32, 33]. In human cancer cells, which are responsive to IGF-1, increased expression and tyrosine phosphorylation of IRS-1 have been detected, suggesting that the association of IRS-1 with cellular transformation could be due to its activity as a substrate for the IGF-1 receptor $[42,43]$. Thus, the upregulation of IRS- 1 in insulin-resistant $\mathrm{CHO}$-mut cells could induce some phenotypic change, and increased IRS-1 expression in these cells is possibly associated with the increased cellular proliferation observed in diabetic complications.

Long-term insulin treatment has been reported to induce decreased levels of IRS- 1 protein. In $\mathrm{CHO}$ cells, insulin has been found to decrease IRS-1 content [44]. Treating Fao cells and also 3T3-F442A adipocytes with insulin for a long term has also been shown to decrease IRS-1 protein and phosphorylation levels [45-50]. Since the concentration of insulin that produces a $50 \%$ reduction of IRS- 1 is between 0.01 and $1 \mathrm{nmol} / 1$, well within the physiological range, our results suggest that impaired insulin signalling in $\mathrm{CHO}-$ mut cells may induce a relative increase in IRS-1 protein levels. Although insulin-induced downregulation of IRS-1 in other cells has been shown to be due to an increased rate of degradation 
of IRS-1 protein, we have shown in CHO-mut cells that increased IRS-1 expression is not due to a change in protein turnover but to an increase in IRS1 mRNA expression. Thus, in various diabetic conditions, impaired insulin signalling may upregulate IRS-1, leading to increased IGF-1 signalling and a change in cell growth.

Acknowledgements. The authors are grateful to Dr. E. Araki (Department of Metabolic Medicine, Kumamoto University School of Medicine) for the mouse IRS-1 gene [51], and to Dr. K. Yamagata (Howard Hughes Medical Institute, the University of Chicago) for human insulin receptor cDNA. This work was supported in part by a grant-in-aid to Dr. Kawata (No. 06557058) from the Ministry of Education, Science and Culture of Japan.

\section{References}

1. White MF, Maron R, Kahn CR (1985) Insulin rapidly stimulates tyrosine phosphorylation of a Mr-185000 protein in intact cells. Nature 318: 183-186

2. Sun XJ, Rothenberg P, Kahn CR et al. (1991) Structure of the insulin receptor substrate IRS-1 defines a unique signal transduction protein. Nature 352: 73-77

3. Kahn CR (1994) Banting Lecture. Insulin action, diabetogenes, and the cause of type II diabetes. Diabetes 43: 1066-1084

4. Kahn CR, White MF (1988) The insulin receptor and the molecular mechanism of insulin action. J Clin Invest 82: 1151-1156

5. Rosen OM (1987) After insulin binds. Science 237: 1452-1458

6. Lee TS, Saltsman KA, Ohashi H, King GL (1989) Activation of protein kinase $\mathrm{C}$ by elevation of glucose concentration: proposal for a mechanism in the development of diabetic vascular complications. Proc Natl Acad Sci USA 86: $5141-5145$

7. Inaba T, Ishibashi S, Gotoda T et al. (1996) Enhanced expression of platelet-derived growth factor- $\beta$ receptor by high glucose. Diabetes 45: 507-512

8. Moran A, Brown DM, Kim Y, Klein DJ (1991) Effects of IGF-1 and glucose on protein and proteoglycan synthesis by human fetal mesangial cells in culture. Diabetes 40 : $1346-1354$

9. Fukuda K, Kawata S, Inui Y et al. (1997) High concentration of glucose increases mitogenic responsiveness to heparin-binding epidermal growth factor-like growth factor in rat vascular smooth muscle cells. Atherioscler Thromb Vasc Biol 17: 1962-1968

10. Jacob R, Barrett E, Plewe G, Fagin KD, Sherwin RS (1989) Acute effects of insulin-like growth factor 1 on glucose and amino acid metabolism in the awake fasted rat. J Clin Invest 83 : $1717-1723$

11. Werner H, Shen-Orr Z, Stannard B, Burguera B, T Roberts CT Jr, Leroith D (1990) Experimental diabetes increases insulin like growth factor 1 and 2 receptor concentration and gene expression in kidney. Diabetes 39: 1490-1497

12. Elliton SJ, Striker LJ, Hattori M et al. (1993) Mesangial cells from diabetic NOD mice constitutively secrete increased amounts of insulin-like growth factor-1. Endocrinology 133: 1783-1788

13. Oemer BS, Foellmer HG, Hodgdon-Anandant L, Rosenzweig SA (1991) Regulation of insulin-like growth factor 1 receptors in diabetic mesangial cells. J Biol Chem 266: 2369-2373

14. Dills DG, Moss SE, Klein R, Klein BEK (1991) Association of elevated IGF-1 levels with increased retinopathy in late-onset diabetes. Diabetes 40: 1725-1730

15. Merimee TJ, Zapf J, Froesch ER (1983) Insulin-like growth factors, studies in diabetics with and without retinopathy. N Engl J Med 309: 527-530

16. Ashton IK, Dorman TL, Pocock AE, Turner RC, Bron AJ (1983) Plasma somatomedin activity and diabetic retinopathy. Clin Endocrinol 19: 105-110

17. Wang J, Niu W, Nikiforov Y et al. (1997) Targeted overexpression of IGF-1 evokes distinct patterns of organ remodeling in smooth muscle cell tissue beds of transgenic mice. $\mathbf{J}$ Clin Invest 100: 1425-1439

18. Clemmons DR, Van Wyk JJ (1985) Evidence for a functional role of endogenously produced somatomedin-like peptides in the regulation of DNA synthesis in cultured human fibroblasts and porcine smooth muscle cells. J Clin Invest 75: 1914-1918

19. Howard G, O'Leavy DH, Zaccaro D et al. (1996) Insulin sensitivity and atherosclerosis. Circulation 93: 1809-1817

20. Haffner SM, Stern MP, Hazuda HP, Mitchell BD, Patterson JK (1990) Cardiovascular risk factors in confirmed prediabetic individuals. J Am Med Assoc 263: 2893-2898

21. Ferrannini E, Buzzigoli G, Bonadonna R et al. (1987) Insulin resistance in essential hypertension. N Engl J Med 317: 350-357

22. Epstein SE, Siegall CB, Biro S, Fu YM, FitzGerald D, Pastan I (1991) Cytotoxic effects of a recombinant chimeric toxin on rapidly proliferating vascular smooth muscle cells. Circulation 84: 778-787

23. Fukuda k, Inui Y, Kawata S et al. (1995) Increased mitogenic response to heparin-binding epidermal growth factorlike growth factor in vascular smooth muscle cells of diabetic rats. Arterioscler Thromb Vasc Biol 15:1680-1687

24. Moller DE, Benecke H, Flier JS (1991) Biologic activities of naturally occurring human insulin receptor mutations. J Biol Chem 266: 10995-11001

25. Chomczynski P, Sacchi N (1987) Single-step method of RNA isolation by acid guanidinium thiocyanate-phenolchloroform extraction. Anal Biochem 162: 156-159

26. Ito T, Sasaki Y, Wands JR (1996) Overexpression of human insulin receptor substrate-1 induces cellular transformation with activation of mitogen-activated protein kinases. Mol Cell Biol 16: 943-951

27. Moller DE, Yokota A, White MF, Pazianos AG, Flier JS (1990) A naturally occuring mutation of insulin receptor alanine 1134 impairs tyrosine kinase function and is associated with dominantly inherited insulin resistance. J Biol Chem 265: 14979-14985

28. Chang PY, Goodyear LJ, Benecke H, Markuns JS, Moller DE (1995) Impaired insulin signalling in skeletal muscles from transgenic mice expressing kinase-deficient insulin receptors. J Biol Chem 270: 12593-12600

29. Yoshimura R, Araki E, Ura S et al. (1997) Impact of natural IRS-1 mutations on insulin signals. Diabetes 46: 929-936

30. Myers MG Jr, Grammer TC, Wang LM et al. (1994) IRS1 mediates PI3-kinase and p70s6 k signalling during insulin, IGF-1, and IL-4 stimulation. J Biol Chem 269: 28783-28789

31. Myers MG Jr, White MF (1993) The new elements of insulin signalling. Insulin receptor substrate- 1 and proteins with SH2 domains. Diabetes 42: 643-650

32. Nishiyama M, Wands JR (1992) Cloning and increased expression of an insulin receptor substrate-1-like gene in human hepatocellular carcinoma. Biochem Biophy Res Commun 183: 280-285 
33. D'Ambrosio C, Keller SR, Morrione A, Lienhard GE, Baserga R, Surmacz E (1995) Transforming potential of the insulin receptor substrate-1. Cell Growth Differ 6: 557-562

34. Don A McClain, Maegawa H, Thies RS, Olefsky JM (1990) Dissection of the growth versus metabolic effects of insulin and insulin-like growth factor-1 in transfected cells expressing kinase-defective human insulin receptors. J Biol Chem 265: $1678-1682$

35. Levy-Toledano R, Caro LHP, Accili D, Taylor SI (1994) Investigation of the mechanism of the dominant negative effect of mutations in the tyrisine kinase domain of the insulin receptor. EMBO J 13: 835-842

36. Desbois-mouthon C, Danan C, Ameselem S et al. (1996) Severe resistance to insulin and insulin-like growth factor1 in cells from a patient with leprechaunism as a result of two mutations in the tyrosine kinase domain of insulin receptor. Metabolism 45: 1493-1500

37. Nakae J, Kato M, Murashita M, Shinohara N, Tajima T, Fujieda K (1998) Long-term effect of recombinant human insulin-like growth factor 1 on metabolic and growth control in patient with leprechaunism. J Clin Endocrinol Metab 83: 542-549

38. Quin JD, Fisher BM, Paterson KR, Inoue A, Baestall GH, MacCuish AC (1990) Acute response to recombinant insulin-like growth factor 1 in a patient with mendenhall's syndrome. N Engl J Med 323: 1425-1426

39. Kuzuya H, Matsuura N, Sakamoto N et al. (1993) Trial of insulin-like growth factor 1 therapy for patients with extreme insulin resistance syndromes. Diabetes 42: 696-705

40. Schoenle EJ, Zenobi PD, Torresani T, Wender EA, Zachmann M, Froesch ER (1991) Recombinant human insulinlike growth factor 1 (rh IGF-1) reduces hyperglycemia in patients with extreme insulin resistance. Diabetologia 34: 675-679

41. Myers MG Jr, Sun XJ, White MF (1994) The IRS-1 signalling system. Trends Biochem Sci 19: 289-293
42. Baserga R (1994) Oncogenes and the strategy of growth factors. Cell 79: 927-930

43. Baserga R (1995) The insulin-like growth factor 1 receptor: A key to tumor growth? Cancer Res 55: 249-252

44. Cheatham B, Shoelson SE, Yamada K, Goncalves E, Kahn CR (1993) Substitution of the erbB-2 oncoprotein transmembrane domain activates the insulin receptor and modulates the action of insulin and insulin receptor substrate1. Proc Natl Acad Sci USA 90: 7336-7340

45. K Michael Rice, Marilyn A Turnbow, Charles W Garner (1993) Insulin stimulates the degradation of IRS-1 in 3T3L1 adipocytes. Biochem Biophys Res Comm 190: 961-967

46. Saad MJA, Folli F, C Kahn CR (1995) Insulin and dexamethasone regulate insulin receptors, insulin receptor substrate-1, and phosphatidylinositol 3-kinase in Fao hepatoma cells. Endocrinology 136: 1579-1588

47. Rice KM, Lienhard GE, Garner CW (1992) Regulation of the expression of pp160, a putative insulin receptor signal protein, by insulin, dexamethasone, and 1-methyl-3-isobutylxanthine in 3T3-L1 adipocytes. J Biol Chem 267: 10163-10167

48. Saad MJA, Araki E, Miralpeix M, Rothenberg PL, White MF, Kahn CR (1992) Regulation of insulin receptor substrate-1 in liver and muscle of animal models of insulin resistance. J Clin Invest 90: 1839-1849

49. Saad MJA, Folli F, Araki E, Hashimoto N, Csermely P, Kahn CR (1994) Regulation of insulin receptor, insulin receptor substrate-1 and phosphatidylinositol 3-kinase in 3T3-F442A adipocytes. Effects of differentiation, insulin and dexamethasone. Mol Endocrinol 8: 545-557

50. Matsuda K, Araki E, Yoshimura R et al (1997) Cell-specific regulation of IRS-1 gene expression. Diabetes 46: 354-362

51. Haag III BL, Kahn CR (1994) Cloning of the mouse insulin receptor substrate-1 (IRS-1) gene and complete sequence of mouse IRS-1. Biochim Biophys Acta 1221: 353-356 